\title{
Syllepsis: An Unfought Battle in the Language Wars
}

\author{
Alex Segal \\ Humanities \& Social Sciences, Charles Sturt University \\ Locked Bag 588, Wagga Wagga NSW 2678, Australia \\ E-mail: asegal@csu.edu.au
}

Doi:10.7575/aiac.alls.v.6n.2p.137

URL: http://dx.doi.org/10.7575/aiac.alls.v.6n.2p. 137
Received: 05/12/2014

Accepted: 06/02/2015

\begin{abstract}
Syllepsis (in one meaning of the term) is most commonly thought of as an ungrammatical construction which can in certain contexts function as a figure of speech. Yet the common view is at odds with syllepsis occurring in well-written prose that we experience neither as ungrammatical nor as figurative; and with its being largely ignored by literary and rhetorical analysis. As well as arguing against the common view, the paper considers why the view is so uncontroversial, so common.
\end{abstract}

Keywords: syllepsis, ellipsis, grammar, figure of speech

In 1835, Edgar Allan Poe criticized the prose of a fellow writer of fiction, Theodore Fay - particularly this sentence:

"You are both right and both wrong - you, Miss Romain, to judge so harshly of all men who are not versed in the easy elegance of the drawing room, and your father in too great lenity towards men of sense."

To show that this is an absurdity which is "unworthy of a school-boy," "something new but ... incomprehensible," Poe rewrites the sentence, filling in the gaps:

"You are both right and both wrong - you, Miss Romain, are both right and wrong to judge so harshly of all not versed in the elegance of the drawing-room, and your father is both right and wrong in too great lenity towards men of sense." (pp. 56-57)

What Poe objects to here is most commonly called syllepsis, which the Oxford English Dictionary defines thus: “A figure by which a word, or a particular form or inflection of a word, is made to refer to two or more other words in the same sentence, while properly applying to or agreeing with only one of them (e.g. a masc. adj. qualifying two ns., masc. and fem.; a sing. verb serving as predicate to two subjects, sing. and pl.), or applying to them in different senses (e.g. literal and metaphorical)" ("Syllepsis [Def. 1]," n.d.). Of zeugma, the OED says: "sometimes applied to cases of irregular construction, in which the single word agrees grammatically with only one of the other words to which it refers (more properly called syllepsis n.)" ("Zeugma," n.d.-a).

The OED's describing syllepsis as an irregular construction allows for Poe's censure of Fay. And in our own time, Poe's view is endorsed not only by some Poe scholars (Hayes, 2000; Zimmerman, 2005) but by numerous literary, linguistics and style handbooks that identify an ungrammatical form of what they variously call syllepsis or zeugma (different terms, in this context, for the same thing). The Concise Handbook of Literary and Rhetorical Terms says of a line from Shakespeare's Othello, "She has deceived her father, and may thee" $(2002,1.3 .289)$ that "a single predicate applies to two or more parts of a sentence but lacks grammatical correctness" (Mills, 2013, Entry for Syllepsis). Bryan Garner (2009) seems most concerned about what he calls "the nontransferable auxiliary," which he says "plagues writers who habitually try to express their ideas in the alternative." One of his examples is "Although outside professionals have and will be called in to work on the station, firefighters will do most of the work." Here the auxiliary be is intended to combine with both the auxiliary have and the auxiliary will but agrees only with the latter; in this sense it is non-transferable. So Garner recommends inserting the auxiliary been after have (p. 876). Of "He works his work, I mine" from Tennyson's "Ulysses" (2007, p. 144), The Oxford Dictionary of Literary Terms says that the verb "agrees grammatically with only one of the two elements" to which it relates (Baldick, 2008, Entry for Syllepsis). The Cambridge Dictionary of Linguistics uses "He does his work, and I mine" - a more prosaic version of Tennyson - as an example of a "coordinate structure in which one form of a main verb combines, possibly ungrammatically, with different NPs [noun phrases] or auxiliary verbs" (Brown \& Miller, 2013, Entry for Syllepsis). I think that what this text is suggesting is that the cited syllepsis is ungrammatical. Perhaps saying that the verb "agrees grammatically with only one of the two elements" may not, strictly speaking, entail that the construction as a whole is ungrammatical. But it certainly creates an impression to this effect. 
If, following the OED, we stipulate that syllepsis is a figure - that is, a "form" of expression "deviating from the normal arrangement or use of words" which is "adopted in order to give beauty, variety, or force to a composition" ("Figure [Def. 21]," n.d.) - then it would be odd to criticize (as the manuals invite us to do) some instances of syllepsis for being ungrammatical. I think the OED would better capture the widely held view if it specified that syllepsis is sometimes but not always a figure. At issue in this idea is the commonplace that ungrammatical constructions can, to cite the words of The Princeton Encyclopedia of Poetry and Poetics, "be deployed deliberately by the great poets, whose mastery of language gives them the 'license' to deviate from correct usage" (p. 852). The manual writers would probably regard as figures the passages by Shakespeare and Tennyson that are used to illustrate what syllepsis is; hence the quality of these passages does not in itself call into question the notion that syllepsis is ungrammatical in standard English. Perhaps an alternative explanation is that metrical necessity motivates these passages, as it may also motivate the syllepsis in a couplet of Alexander Pope's The Rape of the Lock:

These swell their prospects, and exalt their pride,

When offers are disdained, and love denied. (2012, p. 557)

The ease with which verse embraces syllepsis needs to be recognized even in considering grammar. But because verse, with its prosody, meter and rhyme, and emphasis on the expression of feeling, may indeed be a special case, my discussion inasmuch as it deals with grammar will focus primarily on prose.

I seek here to refute the view that an expression is ungrammatical merely in virtue of its involving syllepsis and the view that syllepsis can readily be used as a figure of speech, as either a grammar-bending figure or as a figure that does not bend grammar. A definition of syllepsis should not build ungrammaticality into the concept; it should leave open the questions of whether syllepsis is ungrammatical and can function as a specific figure of speech. Thus I propose specifying its defining traits thus: (i) one form of a verb combines with more than one noun phrase or with more than one auxiliary verb; (ii) were the expression rewritten in a way that matched each of the multiple noun phrases or each of the multiple auxiliary verbs with its own verb, then more than one form of the latter would be required.

The ungrammaticality is not self-evident. After all, everyone accepts as grammatical a sentence such as "A lion hunting a flock of sheep or a herd of wild asses is a more poetical object than they" (Hazlitt, 1817, p. 71). Expressed more fully, this would read: "A lion hunting a flock of sheep or a herd of wild asses is a more poetical object than they are." Here "are" can be dropped even though it differs from the "is" with which it is paired. Why then in the sentence "The branches are bare; the sky tonight is a milky violet" should we assume that it is ungrammatical to drop the word "is" because it differs from the verb "are"?

In the easily accessible commentaries on syllepsis there is some mild dissent from the widely held view. Wikipedia says that Tennyson's sentence is "grammatically 'incorrect' according to prescriptivist rules," perhaps implying that it is not really incorrect; but it posits ungrammaticality in speaking of "intentional constructions in which the rules of grammar are bent by necessity or for stylistic effect" ("Zeugma," n.d.-b). Mark Forsyth does not explicitly dispute the ungrammaticality but seems unconcerned by it - at least with respect to the Shakespeare and Tennyson sentences. He writes: "it takes a very odd kind of mind to notice that sort of thing ... the meaning is obvious and nobody would pick up the error without a notepad and too much spare time" (2013, Chapter 22, para. 6). If the alleged error is so undetectable, then we might doubt whether the expressions can be experienced as figures.

The fact that the commonly expressed view receives little, if any, direct and explicit criticism, seems to be connected to the dearth of academic discussion on the topic. Academic linguists do comment on some of the advice that is given by style manuals and popular grammar books and sometimes their comments are very critical. But on the alleged ungrammaticality of syllepsis they seem remarkably silent. One linguist at least rejects the common view. Without commenting on the view as such, the linguist Ana Carrera Hernández contends - as if it were self-evident - that one subject being plural, the other singular is as little a problem in "The boy plays the piano and the girls the guitar" as in "My parents bought the bread and your mother the butter" (2007, p. 2117). The views of academic linguists might seem to have considerable weight here. But with respect to good writing and to style in particular, their authority is widely contested. And in any case The Cambridge Dictionary of Linguistics affirms the common view; and no academic linguist I know of has bothered to contest the common view in an easily accessible context.

Although I will be invoking the work of good and great writers and speakers, I realize that the great can err - even in an otherwise fine sentence:

There is no measure more repugnant to the designs and feelings of Bonaparte than Catholic emancipation; no line of conduct more propitious to his projects than that which has been pursued, is pursuing, and, I fear, will be pursued towards Ireland. (Byron, 1995, p. 314)

The ungrammaticality here is not a figure of speech; if asked to reconsider, Byron would write:

There is no measure more repugnant to the designs and feelings of Bonaparte than Catholic emancipation; no line of conduct more propitious to his projects than that which has been pursued, is being pursued, and, I fear, will be pursued towards Ireland. 
An appeal to the practice of the great writer should not override one's own sense of grammar and style. It is my own sense of grammar - formed in part from reading writers like Byron - that tells me that Byron would have regretted his expression here.

As what I have already said suggests, syllepsis, in the sense that concerns us, has various types - all of which on the orthodox view, as I understand this view, are ungrammatical and can function as figures of speech. But I think we need to consider the various types separately. An obvious division has to do with whether a single form of verb combines with different noun phrases or with different auxiliary verbs. Another division pertains to the placement of the verb. In most cases of what I call "noun phrase syllepsis," the verb follows the first noun phrase that is its subject but precedes the second such noun phrase - as for example, "He works his work, I mine." But sometimes the verb precedes all the noun phrases with which it combines: "Then falls the church, the state, art, letters, life" (Emerson, 2008, p. 33). And occasionally the verb follows all the noun phrases: "I on my horse, and Love on me doth try / Our horsemanships" (Sidney, 2005, p. 141). With respect to what I shall call "auxiliary syllepsis," the single verb sometimes precedes at least one of the auxiliary verbs with which it combines (as in "She has deceived her father, and may thee") and at other times follows all the auxiliary verbs, as in "The problem has and will persist." Some cases of noun phrase syllepsis involve a disjunctive subject - for example, "Nor God nor I delights in perjured men" (Shakespeare, 2009, 5.2.346). In such cases, the verb either follows both noun phrases or precedes both of them: "In perjured men delights neither God nor I." Although I focus on noun phrase syllepsis and auxiliary syllepsis, there are other kinds - for example, a kind ignored by the manuals, perhaps because it is so rare, in which a single auxiliary verb (did) combines with two different main verbs: "Nor ever did he speak nor looked at me" (Rossetti, 2012, p. 152). Expressed more fully this would read: "Nor ever did he speak nor ever did he look at me." I think that this is ungrammatical in standard English and is here a figure of speech - albeit we cannot explain its ungrammaticality and its being a figure of speech merely in terms of its being sylleptic.

Of all the kinds of syllepsis, that involving a disjunctive subject probably receives the most grammatical scrutiny. Here are some examples: "Either you or I am responsible"; "Either you or I is responsible"; "Neither the owners nor the contractor agree"; "Neither the owners nor the contractor agrees." Many commentators affirm the principle "Agreement with the Nearest Adjunct." That is, they treat "Either you or I am responsible" as correct, "Either you or I is responsible" as incorrect - and thereby imply, contrary to the orthodox view of syllepsis, that a sylleptical construction is grammatical. Yet linguist Arnold Zwicky contends that either choice "is going to annoy or baffle a significant number of your readers," and he tentatively recommends avoiding such situations (2009). Although not saying that he shares the annoyance he refers to, Zwicky treats this kind of sylleptic expression as problematic, stylistically if not grammatically, providing some support for the grammatical concern about syllepsis. But at issue is only disjunctive subject syllepsis, not syllepsis in general. And as what grammar-bending there is arises from a situation, not a choice, figurativeness does not arise - even when gifted writers are in this situation: "neither he nor I is making any assertion" (Russell, 1999, p. 161); "Neither she nor I is devaluing anyone else's life" (Tallis, 2014, p. 261).

Possibly the most common kind of syllepsis is the noun phrase syllepsis where the subject is not disjunctive and the verb follows the first noun phrase that is its subject but precedes the second. The most commonly cited example is Tennyson's "He works his work, I mine." But there are many other fine examples - and in prose too:

His style is boisterous and rough-hewn; his rhyme incorrigibly lewd, and his numbers perpetually harsh and illsounding. (Dryden, 1808, p. 403)

Gaiety is to good humour as animal perfumes to vegetable fragrance; the one overpowers weak spirits, and the other recreates and revives them. (Johnson, 2009, p. 98)

$\ldots$ their jests are commonly gross, and their pleasantry licentious (Johnson, 2009, p. 363)

... toleration is odious to the intolerant, freedom to oppressors, property to robbers, and all kinds and degrees of prosperity to the envious. (Burke, 2000, p. 255)

... the mother was found to be intolerable and the younger sisters not worth speaking to (Austen, 1966, p. 13)

Mr. and Mrs. Morland were all compliance, and Catherine all happiness. (Austen, 2003, p. 18)

I have never seen his journals, nor he mine (Byron, 1849, p. 106)

... her complexion was remarkably fair and brilliant, her head small, neck long, chin well turned, but very short, lips thin and red, eyes clear hazel, quick, and penetrating, but entirely destitute of poetry or feeling. (A. Brontë, 2009, p. 50) 
It had been a maxim with the father of Pierre, that all gentlemanhood was vain; all claims to it preposterous and absurd ... (Melville, 1971, p. 6)

Very graceful was the lady's mien, choice her appointments (C. Brontë, 1909, p. 336)

He thought religion was a very excellent thing, and Aristotle a great authority, and deaneries and prebends useful institutions (Eliot, 1998, p. 138)

The first two are bad motives, the third a good, and the last a mixed one. (Fowler, 1906, p. 20)

... the bend of her head was proud, her grey eyes clear and dilated (Lawrence, 1995a, p. 56)

While his forehead was being wrinkled and his jaws painted black and blue by the elderly man, he listened distractedly to the voice of the plump young jesuit ... (Joyce, 1992, p. 89)

They were not important to him, save as instruments, nor he to them, save as a supreme instrument of control. (Lawrence, 1995b, p. 231)

"Belongings," beyond the bare necessaries of life, are nothing but a burden; the man who has them really belongs to them, and not they to him. (Lovejoy, 1942, p. 465)

Within the framework of the novel, the revolt of the dodger is non-narratable, its consequences, unthinkable. (Ginsburg, 1987, p. 225)

Bad books become unreadable and bad music unlistenable. (Giddins, 2010, p. 30)

Landy's writing is accessible and his analyses sound. (Watt, 2011, p. 110)

We have seen that Edgar Allan Poe, himself a great writer, believes that this kind of syllepsis is ungrammatical; and his believing this is perhaps the most powerful evidence I know for the belief. But he also believes this kind of syllepsis is very rare, especially in fine writing; and that he is mistaken about this is shown by the lucid, polished prose I have just cited - prose which we experience neither as grammar-bending nor as involving the overriding of one linguistic value by another. Necessity may seem to motivate sylleptic expressions that are much more concise than the alternatives; but not all these expressions are much more concise than the alternatives. And as the syllepsis-free versions, even when inferior, are unexceptional, at issue is not good sense trumping good grammar of the kind evoked by E. B. White when he says he prefers "The worst tennis player around here is me" to "The worst tennis player around here is I" (Strunk \& White, 2001, p. 78). The prose is by gifted authors who rarely stumble and are unlikely all to have stumbled over the same thing; and some of this prose has been studied by numerous literary critics who have not, as far as I am aware, thought it ungrammatical or grammar-bending. I doubt whether ungrammaticality can thus escape the notice of so many fine writers and so many who cultivate sensitivity to language.

Nor do these instances of syllepsis seem to be figures of speech - at least not inasmuch as they are syllepses. Where noun phrase syllepsis of this kind may seem to be a figure - as in Sir Francis Bacon's "Histories make men wise; poets, witty; the mathematics, subtile; natural philosophy, deep; moral, grave; logic and rhetoric, able to contend" (2008, p. 109) - at issue, I think, is ellipsis: "an omission of expected words" (Farnsworth, 2011, Chapter 12, para. 1) which embraces syllepsis, and which is not thought to be itself ungrammatical.

The qualities of ellipsis explain why sylleptic sentences may be preferable to non-sylleptic equivalents - and preferable in various ways. Mark Forsyth is rather dismissive of ellipsis, arguing that ellipsis is effective only if it expresses contempt, a refusal to "waste time on main verbs, or breath on you" - as when Tennyson "had Ulysses dismiss his son's entire life with the words 'He works his work; I mine'"; that speakers of English are unused to and shocked by the distance - "miles away" - between noun and verb in ellipsis; and that isocolon is in general preferable to ellipsis: " "My true love hath my heart and I have his' wouldn't be nearly as beautiful if it were 'My true love hath my heart, I his' " (2013, Chapter 22, para. 6 and 8). Yet surely any contempt in Tennyson's line is in Ulysses' verbless reference to himself; and the verblessness in ellipsis may render a clause more ethereal, more floating, more beautiful: "The branches are bare, the sky tonight a milky violet" (Seth, 1999, p. 3). And in this ellipsis the distance between noun phrase and verb is not that great; and where it is greater (for example, "Her purity was supposed to be her chief beauty her blushes, her great grace" (Woolf, 2008, p. 141), I doubt that it shocks readers. 
But Forsyth seems right to assimilate the common kind of noun phrase syllepsis to the common kind of noun phrase ellipsis. Sometimes such syllepsis can sound a little casual: "The sandy road was gone and the paddocks and bungalows the other side of it" (Mansfield, 1981, p. 205); "My mother is hot-tempered as I am, my father and sister not at all" (Eyres, 2013, p. 197). But no more so than similar syllepsis-free elliptical sentences: "The sandy roads were gone and the paddocks and bungalows the other side of them"; "My mother is hot-tempered as my father is, my sister not at all." On rare occasions an expression involving noun phrase syllepsis is less clear than a non-sylleptical equivalent. Compare "where the understanding of an Author is not convinced, or his feelings altered, this cannot be done without great injury to himself" (Wordsworth, 1963, p. 26) with "where the understanding of an Author is not convinced, or his feelings are not altered, this cannot be done without great injury to himself." But the original is also less clear than an alternative sylleptic version: "where the understanding of an Author is not convinced, or his feelings not altered ...." And it is no more unclear than the syllepsis-free "where the understanding of an Author is not convinced, or his feeling altered ...." The density of Bacon's sentence that I cited above pertains as much to a similar syllepsis-free sentence: "Histories make men wise; poets, witty; the mathematics, subtile; natural philosophies, deep; moral, grave; logic and rhetoric, able to contend."

Ward Farnsworth ascribes "brevity, energy, and elegance" to some instances of ellipsis, arguing it can tie "two phrases together more snugly and strengthen the felt link between them" - for example, by keeping "opposites closer together" (2011 Chapter 12, para. 1 and 8). He illustrates his claims by citing sentences that are sylleptical as well as elliptical yet he ignores the syllepses - rightly I believe:

Resistance to power has shut the door of the House of Commons to one man; obsequiousness and servility, to none. (Burke, 1834, p. 142)

The dull distinguish only races or nations, or at most classes, but the wise man, individuals. (Thoreau, 1975, p. 266)

For I am critic and creator; and as critic, in cruelty surpass all critics merely, as a tiger, jackals. (Melville, 1855, p. 323)

And Farnsworth's attitude is typical. If they are not writing handbooks of literary terms or listing figures used by an author - as Miriam Joseph (1947, p. 58) lists "I have no more to reckon, he to spend" from Timon of Athens as an instance of syllepsis in Shakespeare - literary scholars ignore noun phrase syllepsis, never analysing its putative aesthetic or literary qualities, even when it occurs in some of the most famous and analysed passages of English literature:

The Poop was beaten Gold,

Purple the Sails (Shakespeare, 1993, 2.2.198-99)

What men or gods are these? What maidens loth?

What mad pursuit? What struggle to escape? (Keats, 2006, p. 905)

The fact that literary critics ignore the common form of noun phrase syllepsis probably places the onus of proof on those who contend that such syllepsis can function as a figure of speech.

My sense that it cannot so function is tied to my sense that, not being something we register, consciously or unconsciously, it is not used "in order to give beauty, variety, or force to a composition." But I accept that features of literary interest that differ from figures of speech may be as undetectable as I believe noun phrase syllepsis is. Deliberately leaving out a letter from a text - thereby creating a lipogram - "may, if unannounced in the work itself, slip by unnoticed" (The Princeton Encyclopedia of Poetry and Poetics, 2012, p. 809). Announcing an otherwise undetectable noun phrase syllepsis may render it of literary interest. Borrowing an ellipsis that Mark Forsyth (2013, Chapter 22, para. 3) uses to describe ellipsis, and adding the title "Syllepsis," yields a syllepsis that describes syllepsis:

$$
\text { Syllepsis }
$$

Other figures have produced loads of great lines: it some.

Here it is almost as if syllepsis becomes a figure of speech - I say "almost" because on the usual understanding, a figure of speech does not need to be announced to function as such. But whether or not it is a figure of speech here, it acquires, qua syllepsis, a kind of literary interest, I think - but in a circumstance which is quite unusual.

Moreover, although I question whether the common kind of noun phrase syllepsis can function as a figure of speech, I accept that an author's belief to the contrary might matter. Sophie Read responds to the puns in the sermons of Bishop Lancelot Andrewes with reference to his belief - which she herself may disagree with - that puns are "of divine 
institution" and "share in the power ... of the pun on which the Church itself was founded: "thou are Peter [Petrus], and upon this rock [petram] I will build my church" " (2007, p. 88). If a poet used syllepsis believing that it is a grammarbending figure of speech which contributes to discord and thereby, ultimately, to the rich harmony that is Discordia concors, we would arguably need to register the poet's belief and attend to the syllepsis in the poem. The only poem I know of that may use syllepsis in this way is Francis Quarles" "My Beloved is Mine, and I am His," which includes the following:

\author{
He is my Altar; I, his Holy Place; \\ I am his guest; and he, my living food; \\ I'm his by penitence; he mine by grace; \\ I'm his by purchase; he is mine, by blood; \\ He's my supporting elm; and I his vine; \\ Thus I my best beloved's am; thus he is mine. (2003, pp. 162-163)
}

Rarer than noun phrase syllepsis is "auxiliary syllepsis," in which a single form of a verb (either a main verb or an auxiliary verb) combines with more than one auxiliary verb - albeit this may have something to do with auxiliary ellipsis being rarer than noun phrase ellipsis. More importantly, auxiliary ellipsis is rarer than the syllepsis-free equivalent. But it is not that rare. Indeed, auxiliary syllepsis in which the single form of the verb follows all the auxiliary verbs is likened to a plague by Bryan Garner. So if the relative rarity of auxiliary syllepsis suggests it is ungrammatical, its not being very rare may suggest the reverse. Moreover, some rare expressions strike us as grammatical; and rarity may result from editing that follows style manual advice. Linguist Jonathon Owen argues that if "editors have been changing restrictive which to that" (and thereby increasing the frequency of restrictive that), the frequency of restrictive that is evidence not "that there's a good reason for the recommendation" but only that "editors believe there's a good reason" (2013). So my discussion does not focus on frequency.

The case where the single verb is placed before at least one of the auxiliary verbs with which it combines is often illustrated by the quotation from Othello. Here are other examples:

You have loved before, and may again. (Griffith \& Griffith, 1757, p. 126)

Death, when we meet the Spectre in our walks,

As we did yesterday and shall tomorrow,

Soon grows familiar (Rogers, 1869, p. 361)

"He dines and does the honours of your board to-day, as he did yesterday, and will tomorrow." (Lever, 1898, p. 247)

... it is an old saying that what does happen has happened before, and may again (Reade, 1871, p. 348)

The more I saw the less they would (James, 1981, p. 43)

They may even stop the wars, as they have done before and will again (Faulkner, 1978, p. 45)

But, she continues, that was "easy," echoing Jesus' words in Matt. 11.28-30, as she did in the sixth poem's debate and will again in this poem's second stanza. (Oberhaus, 1995, p. 158)

Throughout the autumn various pamphleteers attempted to show that Guienne had once enjoyed estates, and ought to again. (Doyle, 1974, p. 289)

... this problem is related to the schema of primary and secondary causation, which we have discussed before and will again (Griffin, 1976, p. 128)

The past has helped to liberate the poet's culture before and may again. (Radzinowicz, 1990, p. 283)

... this court was soon to learn - as others had before and would again in the future - that Cavendishes were no slavish followers of any one party in parliament or ruling group at court. (Jungnickel \& McCormmach, 1996, p. 19)

Adherence to the collective ideal has proved successful in the past, and will again, as we will see in The Sirian Experiments. (Waterman, 2006, p. 42) 
Politics changed, as it had before and would again, when new military technology and tactics created new kinds of warriors in the seventh century BC. (Pavlac, 2011, p. 53)

Were these syllepses drawn to their authors' attention, I doubt that the authors would either wish to eliminate them as ungrammatical or affirm them as figures of speech - at least as figures of speech tied specifically to syllepsis. Inasmuch as syllepsis is at issue, the expressions - whether in verse or prose - seem standard and grammatical; and not especially expressive, poetic, playful or daring. In terms of figurativeness, the sylleptic expression "The more I saw, the less they would" is on all fours with the syllepsis-free expression "The more I hurt her, the less they would."

I respond differently, though, to the kind of auxiliary syllepsis in which multiple auxiliary verbs combine with and precede a single form of a verb. Here are some instances in academic prose:

Programs embodied in the International Geosphere Biosphere Program (IGBP) need to know how permafrost has and may respond to climate changes (Permafrost Response on Economic Development, Environmental Security and Natural Resources, 2001, p. 27)

The NAO has been quite unprecedented in its openness about the way it has, and will, undertake these VFM audits. (English, Guthrie, Broadbent, \& Laughlin, 2010, p. 69)

One was a provision for self-certification by entities that they have and will comply with anti-bribery laws (Arrowsmith, Linarelli, \& Wallace, 2000, p. 60)

The work has and will be carried out when the children are about (Bilton, 1994, p. 36)

Several purification methods have and will be used in the IGIV purification process. (Siegel, 2006, p. 524)

difference has, and will be, used as a means by which to resist the acceptance of women into the legal profession and judiciary (Feminist perspectives on public law, 2013, p. 97)

Technology notwithstanding, we always have and will be in need of more good teachers. (Klinge, 1974, p. 154)

I think it likely that their authors, if given the opportunity, would welcome the chance to eliminate these syllepses. I experience them as slipshod; as yielding an impression of imprecision in a context (academic writing) where such an impression matters - albeit this impression is not actual ambiguity or even potential ambiguity.

Bryan Garner perhaps implies that this kind of syllepsis has a greater risk of actual ambiguity than its non-sylleptic equivalent. He contends that in the sylleptic sentence "Although outside professionals have and will be called in to work on the station, firefighters will do most of the work," the verb called "is nonsensically made both active and passive" (Garner, 2009, p. 876). He must have in mind that on a certain interpretation of this sentence, its more explicit rewriting contains an active and a passive called: "Although outside professionals have called in to work and will be called in to work on the station, firefighters will do most of the work." But if the sentence involves syllepsis, the main verb is only passive. For in its more explicit rewriting, both occurrences of called are passive: "Although outside professionals have been called and will be called in to work on the station, firefighters will do most of the work." Nevertheless, the sylleptic sentence, unlike its syllepsis-free equivalents, is ambiguous.

Another kind of ambiguity pertains to the following sylleptic sentence:

As this text has and may take different forms - paper and electronic - we have decided here to use two styles of referencing in the same text. (Edwards, Nicoll, Solomon, \& Usher, 2004, p. 70)

The syllepsis-free equivalent would be: "As this text has taken and may take different forms - paper and electronic - we have decided here to use two styles of referencing in the same text." But the sylleptic sentence, unlike the syllepsis-free sentence, could also express a different proposition: "As this text has different forms (paper and electronic) and may take different forms (paper and electronic), we have decided here to use two styles of referencing in the same text."

We need to note that an ambiguity can pertain to the syllepsis-free equivalents of this kind of sylleptic sentence. The syllepsis free expression "difference has been and will be used as a means" has the intended meaning "has been used as a means and will be used as a means"; but the expression could also, at a pinch, mean: "has existed and will be used as a means." However, in my judgment, such ambiguity is less problematic than the ambiguity that sometimes pertains to 
sylleptic sentences. For in most contexts the awkwardness of using "has been" to express the meaning "has existed" precludes the unwanted meaning.

It is true that many, indeed most, sentences involving this kind of syllepsis are unambiguous - consider, for example, "The work has and will be carried out." Moreover, the fact that an expression (or a kind of expression) is sometimes ambiguous neither warrants avoiding it generally nor renders the expression ungrammatical. Think of the expressions "I saw her duck" and "I went to the bank." But it may be that even where the intended meaning of a sylleptic sentence of this kind is clear enough, the syllepsis-free equivalent is clearer still. And when there is no ambiguity, it seems absurd and artificial to seek an alternative for "I went to the bank" but not absurd or artificial to replace a sylleptic expression of the kind we are considering with the syllepsis-free equivalent. So I think it is probably no accident that in edited academic prose, sylleptic expressions of this kind are much less frequent than the syllepsis-free equivalents.

The syllepsis-free alternative constructions are more common not just in edited writing but in writing of some distinction. Here are some examples, including two which involve the kind of ambiguity that can arise from the syllepsis-free construction:

For these three be they which ... to imitate, borrow nothing of what is, hath been, or shall be. (Sidney, 1831, p. 17)

He knows at once what is, has been and will be (Charnock, 1864, p. 858)

Thus it always is, has been and will be. (Adams \& Adams, 2007, p. 143)

Is there then nothing that has lasted, and will last for ever? (Arnold, 1843, p. 11)

Let us say there are a thousand millions of men on the earth at this time; who can weigh and measure the aggregate of pain which this one generation has endured and will endure from birth to death? Then add to this all the pain which has fallen and will fall upon our race through centuries past and to come. (Newman, 1870, p. 393)

The principles of strategy may be immutable. It is certain they have been, and shall be again, disregarded from timidity, from blindness, through infirmity of purpose. (Conrad, 1925, p. 188)

There are, have been, and will be bad laws, bad morals, and bad societies. (Devlin, 1965, p. 94)

I can imagine that authorial inattentiveness explains the so far presented auxiliary syllepses in which the single form of the verb follows the auxiliary verbs. But I sense no such inattentiveness in the just quoted syllepsis-free sentences. So taking all this into account, I think that in the context of academic and professional writing, Garner is right to discourage this kind of auxiliary syllepsis; and a copy-editor would be right to replace it with the syllepsis-free equivalent.

In this kind of auxiliary syllepsis (in contrast with the other kind we have considered), the single form of the verb occurs at the point that we can grasp the meaning of the sylleptic expression and thus can pause in our reading; hence this verb, which does not altogether fit, can claim our attention - leading to a sense of incongruity. But this incongruity seems to go unnoticed in contexts where a sense of precision and detachment matter less. Here is this kind of syllepsis in Addison, a writer noted for conversational prose:

From what has, or will be said, I hope no Consequence can be extorted implying that I would have any young Fellow spend more Time than the common Leisure which his Studies require, or more Money than his Fortune or Allowance may admit of, in the pursuit of an Acquaintance with his Betters. (Addison, 1864, p. 73)

And here it is in edifying prose:

These facts being so, as observation and experience attest, it follows, not merely that we form at this moment a part of one great whole, but that we ever have and ever shall form a part of the same. (Wright, 1829, p. 38)

The reciprocation of the mind of man under the impressions of that spirit which "giveth it an understanding," is that spiritual intercourse which constitutes essential divine worship, and ever has and will ever remain to be, the alone basis of all true religion and piety. (Cockburn, 1829, p. 27) 
Therefore, if the child of God desire to preserve a faith pure and undefiled, he must keep to the company of the Saints, and to that right acknowledgment of all Christian doctrine, to that sound interpretation of Holy Scripture, which the voice of the whole Christian world has ever, and ever shall, declare. (Jebb, 1840, p. 351)

Inordinate ambition, wantoning in power and spurning the humble maxims of justice, has, ever has and ever shall end in ruin. (Corwin, 1844, p. 43)

But "the kingdom of our Lord and of his Christ," is "an everlasting kingdom." Ichabod has not, and never shall be, written over its institutions. Its glory shall never depart. (Lang, 1863, p. 264)

True science has never and never will contradict religion (Breen, 2013, p. 12)

His providential care for man, his beloved creation, has not and never shall cease while the earth stands. (Beall, 2013, p. 239)

The church has never, and never will replace Israel or the Jewish people. (Hazelwood, 2014, p. 147)

Authorial inattentiveness is not at issue here. This prose would be less stirring if it smacked of pedantry - as it might if it were free of syllepsis. In "The church has never, and never will replace Israel or the Jewish people," the use of syllepsis adds intensity, enabling an emphasis on the word never. Is there a figure of speech here? I think the vagueness of the concept figure of speech makes it difficult to give a definitive answer. But I would not rule out seeing a figure of speech here; at issue is a departing from the expected word order. Even so, I am inclined to say that it is for reasons of style not grammar that we should avoid such syllepsis in standard academic prose. But whatever one says, I think that copy-editors should not "correct" the syllepsis that contributes to an edifying tone.

Let's now consider a couple of verse examples, both from Shakespeare:

Thoughts tending to content flatter themselves

That they are not the first of fortune's slaves,

Nor shall not be the last; like silly beggars

Who sitting in the stocks refuge their shame,

That many have and others must sit there (Shakespeare, 2010, 5.5.23-27)

For your great graces

Heaped upon me, poor undeserver, I

Can nothing render but allegiant thanks,

My prayers to heaven for you, my loyalty,

Which ever has and ever shall be growing,

Till death, that winter, kill it. (Shakespeare, 2007, 3.2.174-79)

Here, remote from a context in which an impression of conceptual precision is sought, syllepses do not seem slipshod. "Which ever has and ever shall be growing" sounds less pedantic and thus better than the syllepsis-free equivalent: "Which ever has been and ever shall be growing." But because in the context of verse this kind of syllepsis is less likely to stand out than it does even in edifying prose, I am less inclined to see figures of speech here. It is true that unlike the noun phrase syllepsis in the prose of great authors such as Johnson, Austen and Lawrence, these auxiliary syllepses in Shakespeare have been classified as ungrammatical by some literary scholars (Hunter, 1869, p. 110; Jackson, 1819, p. 255 ) - and if they are experienced as ungrammatical yet deliberate, then they will be experienced as figures of speech. But I think classifying them as ungrammatical is probably not useful, even though I can see the motivation for doing so.

Although I reject the common view of syllepsis, its lure is obvious. After all, the idea of ungrammaticality easily gets built into the definition - albeit not inevitably. Moreover, it seems natural to think that determining whether a sentence is grammatical involves checking that its parts hang together; and the parts of a sylleptic sentence (if considered abstractly) seem not to hang together. If you are like me, you will feel uncomfortable with disjunctive subject syllepsis and with one form of auxiliary syllepsis - at least in many of its occurrences; and readily assume that this discomfort arises simply from the non-agreement of the parts of the expression, and that this non-agreement is a flaw in all forms of syllepsis and a matter of grammar rather than style. 
But I doubt this explains why the view is so extremely common. After all, controversy attends the widespread, seemingly commonsensical view that standard English is better than non-standard English. Indeed, in academia more common is the denial of this view. The political aspect of this issue may seem to differentiate it from syllepsis. Yet some controversial language issues are apparently non-political - for example, the idea that the relative pronoun that should introduce all restrictive relative clauses and which should introduce only non-restrictive clauses. So it might be instructive to compare syllepsis with that/which - starting with Henry Fowler's famous injunction:

if writers would agree to regard that as the defining relative pronoun and which as the non-defining, there would be much gain both in lucidity and in ease. Some there are that follow this principle now; but it would be idle to pretend that it is the practice either of most or of the best writers (The New Fowler's Modern English Usage, 1996, p. 774)

The idea of improving language, which Fowler invokes, arouses strong passions, particularly when the proposal conflicts with what most or the best writers do. Were syllepsis subject to a similar injunction, it would I think be more controversial. But syllepsis being less frequent than restrictive which, syllepsis-detractors have less motivation to agitate than restrictive-which detractors. Relative clauses being common, Fowler's injunction pertains to the writing practices of us all. Arising only rarely, the question of whether or not to use syllepsis can be easily ignored; and has perhaps been passed over by copy-editors. So it may be that the editing out of syllepses is less likely to disconcert writers than the editing out of restrictive whiches. Finally, syllepsis - or at least noun phrase syllepsis - is I think less interesting from a literary point of view than are relative pronouns; indeed, it might seem so boring as not to be worth bothering with.

But although this appearance of unimportance may help explain the indifference, it does not justify it. A copy-editor who, accepting the orthodoxy that syllepsis as ungrammatical, replaced "In the experience of beauty the world comes home to us, and we to the world" (Scruton, 2009, p. 67) with "In the experience of beauty the world comes home to us, and we come home to the world" would render the world a little less beautiful - a loss which is not a matter of the loss of syllepsis as a figure of speech. And Poe's thralldom to the accepted view leads him to ridicule a fine sentence, ridicule which is a travesty of a concern for good writing. More generally, the widely accepted view - the view found in dictionaries, in style manuals, in dictionaries of literary terms - involves an incoherent notion of language that abstracts from our experience of language. Given the difficulty of lucid thought about language, the fact that such a notion has sway in general academic culture should not surprise us; but its sway in institutions devoted to language and literature is altogether more disconcerting and unexpected.

\section{References}

Adams, A., \& Adams, J. (2007). My dearest friend: Letters of Abigail and John Adams. Boston, MA: Harvard University Press.

Addison, J. (1864). The works of Joseph Addison (Vol. 2). New York, NY: Harper \& Brothers.

Arnold, T. (1843). Christian life, its hopes, its fears, and its close (2nd ed.). London: B. Fellowes.

Arrowsmith, S., Linarelli, J., \& Wallace, D. (2000). Regulating public procurement: National and international perspectives. The Hague: Kluwer Law International.

Austen, J. (1966). Pride and prejudice. New York, NY: Norton.

Austen, J. (2003). Northanger Abbey. Harmondsworth: Penguin.

Bacon, F. (2008). The essays or counsels, civil and moral, of Francis Bacon. Rockville, MD: Arc Manor.

Baldick, C. (2008). The Oxford dictionary of literary terms Oxford: Oxford University Press. Kindle Edition.

Beall, R. (2013). Thoughts and gleanings. Bloomington, IN: WestBow Press.

Bilton, H. (1994). The nursery class garden: Designing and building an outdoor environment for young children. Early Years: An International Research Journal, 14(2), 34-37.

Breen, E. (2013). The human mind and belief. Bloomington, IN: AuthorHouse.

Brontë, A. (2009). The tenant of Wildfell Hall. Toronto, ON: Broadview.

Brontë, C. (1909). Villette. London: Dent.

Brown, K., \& Miller, J. (2013). The Cambridge dictionary of linguistics Cambridge: Cambridge University Press, Kindle edition.

Burke, E. (1834). The works of the Right Hon. Edmund Burke. London: Holdsworth \& Ball.

Burke, E. (2000). On empire, liberty and reform: Speeches and letters (D. Bromwich Ed.). New Haven, CT: Yale University Press.

Byron, L. (1849). The works of Lord Byron; in verse and prose. Hartford: S. Andrus.

Byron, L. (1995). Selected poetry and prose. London: Routledge.

Charnock, S. (1864). The complete works of Stephen Charnock (Vol. 1). Edinburgh: James Nichol. 
Cockburn, J. (1829). A review of the general and particular causes which have produced the late disorders and divisions in the Yearly meeting of Friends, held in Philadelphia. Philadelphia, PA: Philip Price.

Conrad, J. (1925). The mirror of the sea. Edinburgh: John Grant.

Corwin, T. (1844). On the Mexican War, Speech to the American Senate The Whig almanac and United States register for 1844. New York, NY: Greeley and McElrath.

Devlin, P. (1965). The enforcement of morals. Oxford: Oxford University Press.

Doyle, W. (1974). The Parlement of Bordeaux and the end of the Old Régime, 1771-1790. London: Ernest Benn.

Dryden, J. (1808). The works of John Dryden (W. Scott Ed.). London: William Miller.

Edwards, R., Nicoll, K., Solomon, N., \& Usher, R. (2004). Rhetoric and educational discourse: Persuasive texts. London: Routledge.

Eliot, G. (1998). The mill on the floss. Oxford: Oxford University Press.

Emerson, R. W. (2008). Emerson: Political writings (K. S. Sacks Ed.). Cambridge: Cambridge University Press.

English, L. M., Guthrie, J., Broadbent, J., \& Laughlin, R. (2010). Performance audit of the operational stage of longterm partnerships for the private sector provision of public services. Australian Accounting Review, 20(1), 64-75.

Eyres, H. (2013). Horace and me: Life lessons from an ancient poet. London: Bloomsbury.

Farnsworth, W. (2011). Farnsworth's classical English rhetoric. Boston, MA: David R. Godine, Kindle Edition.

Faulkner, W. (1978). A fable. New York, NY: Random House.

Feminist perspectives on public law. (2013). (S. Millns \& N. Whitty Eds.). London: Routledge.

Figure [Def. 21]. (n.d.). Oxford English online dictionary. Retrieved 25 September, 2014, from http://dictionary.oed.com

Forsyth, M. (2013). Elements of eloquence: How to turn the perfect English phrase. London: Icon Books, Kindle edition.

Fowler, H. W. F., Francis George. (1906). The King's English. Oxford: Clarendon Press.

Garner, B. (2009). Garner's modern American usage (3rd ed.). Oxford: Oxford University Press.

Giddins, G. (2010). Warning shadows: Home alone with classic cinema. New York, NY: Norton.

Ginsburg, M. P. (1987). Truth and persuasion: The language of realism and of ideology in Oliver Twist. Novel: A Forum on Fiction, 20(3), 220-236.

Griffin, D. R. (1976). God, power, and evil: A process theodicy. Louisville, KY: Westminster John Knox Press.

Griffith, R., \& Griffith, E. (1757). A series of genuine letters between Henry and Frances. London: W. Johnston.

Hayes, K. J. (2000). Poe and the printed word. Cambridge: Cambridge University Press.

Hazelwood, M. (2014). The world system equals the Beast of Revelation. Bloomington, IN: Archway Publishing.

Hazlitt, W. (1817). Characters of Shakespear's plays. London: R. Hunter.

Hernández , A. C. (2007). Gapping as a syntactic dependency. Lingua, 117(12), 2106-2133. doi: 10.1016/j.lingua.2007.01.004

Hunter, J. (1869). Shakespeare's Henry the Eighth. London: Longmans, Green and Company.

Jackson, Z. (1819). Shakspeare's genius justified. London: J. Johnson.

James, H. (1981). The turn of the screw and other short fiction. New York, NY: Random House.

Jebb, J. (1840). The divine economy of the church. London: Duncan and Malcolm.

Johnson, S. (2009). Samuel Johnson: Selected writings (P. Martin Ed.). New York, NY: Harvard University Press.

Joseph, M. (1947). Shakespeare's use of the arts of language. New York, NY: Columbia University Press.

Joyce, J. (1992). A portrait of the artist as a young man. Harmondsworth: Penguin.

Jungnickel, C., \& McCormmach, R. (1996). Cavendish. Philadelphia, PA: American Philosophical Society.

Keats, J. (2006). Ode on a grecian urn. In J. Stillinger (Ed.), The Norton anthology of English literature (8th ed., Vol. D, pp. 906-906). New York, NY: Norton.

Klinge, P. L. (1974). American education in the electric age: New perspectives on media and learning. Englewood Cliffs, NJ: Educational Technology.

Lang, A. (1863). Practical exposition of the first chapter of the Epistle to the Hebrews verses 5-9. The Evangelical repository. London: Jackson, Walford \& Hodder.

Lawrence, D. H. (1995a). The rainbow. Harmondsworth: Penguin.

Lawrence, D. H. (1995b). Women in love. Harmondsworth: Penguin.

Lever, C. J. (1898). Roland Cashel. London: Downey \& Company. 
Lovejoy, A. (1942). The communism of Saint Ambrose. Journal of the History of Ideas, 3(4), 458-468.

Mansfield, K. (1981). The collected stories. Harmondsworth: Penguin.

Melville, H. (1855). Mardi: And a Voyage thither. New York, NY: Harper \& Brothers.

Melville, H. (1971). Pierre, or the ambiguities. Evanston, IL: Northwestern University Press.

Mills, M. S. (2013). Concise handbook of literary and rhetorical terms: Esteps-Nichols Publishing, Kindle edition.

The new Fowler's modern English usage. (1996). (R. W. Burchfield Ed. 3rd ed.). Oxford: Oxford University Press.

Newman, J. H. (1870). An essay in aid of a grammar of assent (2nd ed. Vol. 1). London: Burns \& Oates.

Oberhaus, D. H. (1995). Emily Dickinson's fascicles: Method and meaning. University Park, PA: Pennsylvania State University Press.

Owen, J. (2013). My thesis. Arrant pedantry. Retrieved 1 October, 2014, from http://www.arrantpedantry.com/2013/05/16/my-thesis/

Pavlac, B. A. (2011). A concise survey of Western Civilization: Supremacies and diversities throughout history. Plymouth: Rowman \& Littlefield.

Poe, E. A. (1835). Review of Norman Leslie. Southern Literary Messenger, 2(1), 54-57.

Pope, A. (2012). The rape of the lock. In J. Black, L. Conolly \& K. Flint (Eds.), The Broadview anthology of British literature (2 ed., Vol. 3, pp. 555-568). Toronto, ON: Broadview Press.

The Princeton encyclopedia of poetry and poetics. (2012). (R. Greene \& S. Cushman Eds. 4th ed.). Princeton, NJ: Princeton University Press.

Quarles, F. (2003). My beloved is mine and I am his. In G. Rowell (Ed.), Love's redeeming work: The Anglican quest for holiness (pp. 162-163). Oxford: Oxford University Press.

Radzinowicz, M. A. (1990). Reading paired poems nowadays. Lit: Literature Interpretation Theory, 1(4), 275-290.

Read, S. (2007). Puns: Serious wordplay. In S. Adamson, G. Alexander \& K. Ettenhauer (Eds.), Renaissance figures of speech (pp. 81-94). Cambridge: Cambridge University Press.

Reade, C. (1871). Peg Woffington, Christie Johnstone: and other stories. Boston, MA: Fields, Osgood \& Co.

Rogers, S. (1869). A funeral The poetical works of Samuel Rogers (pp. 359-362). London: Routledge.

Rossetti, D. G. (2012). Willowwood 1. In P. Negri (Ed.), English Victorian poetry: An anthology (pp. 152-153). Mineola, NY: Dover Publications.

Russell, B. (1999). Russell on ethics: Selections from the writings of Bertrand Russell (C. Pigden Ed.). Abingdon: Routledge.

Scruton, R. (2009). Beauty. Oxford: Oxford University Press.

Seth, V. (1999). An equal music. Harmondsworth: Penguin.

Shakespeare, W. (1993). Antony and Cleopatra (J. Andrews Ed.). London: Dent.

Shakespeare, W. (2007). Henry VIII The complete works of William Shakespeare. Ware, Hertfordshire: Wordsworth Editions.

Shakespeare, W. (2009). Love's labour's lost (W. Carroll Ed.). Cambridge: Cambridge University Press.

Shakespeare, W. (2010). Richard II (J. Bate \& E. Rasmussen Eds.). Basingstoke: Macmillan.

Sidney, P. (1831). The defence of poesy. Cambridge: Hilliard \& Brown.

Sidney, P. (2005). Sonnet 49, Astrophel and Stella. In R. Blaisdell (Ed.), Elizabethan poetry: An anthology (pp. 141142). Mineola,, NY: Dover Publications.

Siegel, J. (2006). Safety considerations in IGIV utilization. International Immunopharmacology, 6(4), 523-527.

Strunk, W., \& White, E. B. (2001). The elements of style (4th ed.). Boston, MA: Allyn and Bacon.

Syllepsis [Def. 1]. (n.d.). Oxford English online dictionary. Retrieved 25 September, 2014, from http://dictionary.oed.com

Tallis, R. (2014). Reflections of a metaphysical flaneur: And other essays. London: Routledge.

Tennyson, A. (2007). Ulysses. In C. Ricks (Ed.), Tennyson: A selected edition (Revised ed., pp. 138-145). London: Routledge.

Thoreau, H. D. (1975). Early essays and miscellanies. Princeton, NJ: Princeton University Press.

Waterman, D. (2006). Identity in Doris Lessing's space fiction. Youngstown, $\mathrm{OH}$ : Cambria Press.

Watt, A. (2011). The Cambridge introduction to Marcel Proust. Cambridge: Cambridge University Press.

Woolf, V. (2008). Selected essays. Oxford: Oxford University Press.

Wordsworth, W. (1963). Preface to Lyrical ballads. In W. Sutton \& R. Forster (Eds.), Criticism: Theory and practice (pp. 14-27). Indianopolis, IN: Odyssey Press. 
Wright, F. (1829). Course of popular lectures; with 3 addresses on various public occasions, and a reply to the charges against the French reformers of 1789 London: James Watson.

Zeugma. (n.d.-a). Oxford English online dictionary. Retrieved 25 September, 2014, from http://dictionary.oed.com

Zeugma. (n.d.-b). Wikipedia. Retrieved 25 September, 2014, from http://en.wikipedia.org/wiki/Zeugma

Zimmerman, B. (2005). Edgar Allan Poe: Rhetoric and style. Montreal, QC: McGill-Queen's University Press.

Zwicky, A. (2009). Agreement with disjunctive subjects. Language Log. Retrieved December 1, 2014, from http://languagelog.ldc.upenn.edu/nll/?p=1293. 